SHS Web of Conferences 6, 02011 (2014)

DOI: $10.1051 /$ shsconf / 20140602011

(C) Owned by the authors, published by EDP Sciences, 2014

\title{
An Analysis of the Impact of Guangxi Agricultural Finance, Loan and Insurance on the Trade between Guangxi and CAFTA
}

Wang Shukun, Zeng Yanhua

School of Business, Guangxi university, Nanning, P.R.China,Email:wshk2010@163.com

\begin{abstract}
Financial support, agriculture loan and insurance are the main funding modes for the development of agriculture. This study firstly uses software eviews6.0 to make an analysis of the current state of the Trade between Guangxi and CAFTA, and then makes a study of the data of the funds and the trading volume of Guangxi-ASEAN, and comes to the conclusion that the funds involved has an effect on the trade volume. Generally, government fiscal support curbs the trade while the agricultural loan and the agricultural insurance promote it; however, the case in Guangxi seems the opposite. The trade volume is promoted by government financial support while curbed by loan and insurance.
\end{abstract}

Keywords. trade of agricultural product; funds in agriculture; harmony analysis.

China-ASEAN Free Trade Area, (hereafter CAFTA), this country's first free foreign trade zone, was established on January 1, 2010. Guangxi, with its special geographical position, has always been the spotlight in China-ASEAN trade. Located in the subtropical region, the substantial output of tropical agriculture products makes agricultural income an important part of economic growth in Guangxi. Yet except Singapore, Brunei, ASEAN members are all agricultural countries, with relatively high yield of agriculture production and strong competitiveness in this field. Therefore, the ASEAN countries not only provide immense market but also invite fierce competition to Guangxi. Agriculture is a vulnerable industry, misled by comparative benefits, it is difficult to transfer funds to agriculture, and therefore, financial support, loans and insurance are often adopted by central and local government as preferential policies for agriculture. It is of vital importance to ascertain the effects of Guangxi agriculture financial support, agricultural loans and agricultural insurance fund on agricultural products trade between Guangxi and ASEAN, for Guangxi, an underdeveloped province as it is, is the major source of tropical agricultural products in China and serves as the main area in the trade of agricultural products with the ASEAN countries. This paper, from a macro perspective, firstly conducts a descriptive analysis on agriculture financial support, agricultural insurance, agricultural loans and the trade of Guangxi-ASEAN agricultural products, and then comes the two hypotheses with regard to economic significance: " agricultural fund "exerts certain impacts both on importation and exportation, followed by verification of these assumptions and accordingly some suggestive policies are tentatively proposed for the promotion of Guangxi-ASEAN agricultural products trade.

\section{The Status of the Guangxi- ASEAN Trade}

The past few years has witnessed the constantly increasing trade volume in agricultural products

This is an Open Access article distributed under the terms of the Creative Commons Attribution License 2.0, which permits unrestricted use, distribution, and reproduction in any medium, provided the original work is properly cited. 
between Guangxi and ASEAN, the gross trade volume between which increased from one hundred and forty-eight million yuan to nine hundred and thirty-two million yuan from the year of 1996 to 2010 , with an average annual growth rate of $14.05 \%$. Figure 1 demonstrates an overall tendency of increase in exports and imports of agricultural products in Guangxi, particularly the amount of imported agricultural products from ASEAN, which keeps steadily rising, whereas export shows some momentum of declining in certain years. The preferential trade tariffs policies have been constantly promulgated between China and ASEAN Since 2003, in the year of which Chinese and ASEAN implemented WTO the most favored nation tariff rate, covering all tariff items. Chinese and ASEAN began to reduce tariffs on agricultural products since 2004 and till 2006, tariffs on agricultural products was reduced to $0 \%$. Figure 1 indicates a prominent growth of the total amount of agricultural products exported and imported in 2004 and of Chinese agricultural products exported to ASEAN in 2006.

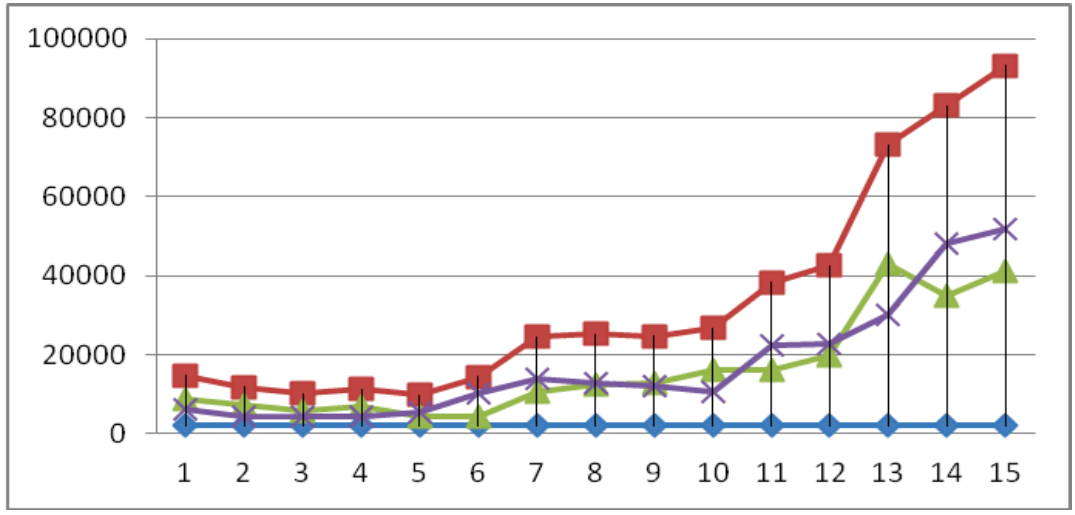

Figure 1. 1995-2010 year, China-ASEAN import and export trend (Data from Nanning customs)
$\mathbf{x}$ : Import volume
:export volume
:total trade volume unit: Ten thousand USD

\section{Analysis of the Situation on Guangxi Agriculture Financial Support, Agricultural Insurance and Agricultural Loans}

\subsection{Agriculture financial support}

The traits, namely long cycle, high risk and low benefit, featuring agriculture, make it an induced and vulnerable industry. Therefore, Capital, technology and human resources can hardly enter the field of Agriculture, particularly with the market echo effect. Governments, NGOs and Agricultural professional cooperatives, therefore play a prominent role in settling the predicament of fund shortage. Guangxi, a critical region supported by western development strategy, has always been the important recipient of China's financial support for agriculture over the years.

Table1. Guangxi financial support for agriculture

unit: ten thousand yuan

\begin{tabular}{ccccccccc}
\hline year & $\mathbf{1 9 9 5}$ & $\mathbf{2 0 0 0}$ & $\mathbf{2 0 0 5}$ & $\mathbf{2 0 0 6}$ & $\mathbf{2 0 0 7}$ & $\mathbf{2 0 0 8}$ & $\mathbf{2 0 0 9}$ & $\mathbf{2 0 1 0}$ \\
\hline agriculture expenditure & 155273 & 278946 & 586690 & 644143 & 898179 & 1393970 & 2107419 & 2602616 \\
total expenditure & 1405892 & 2584866 & 6114806 & 9859433 & 9859433 & 12971100 & 16218218 & 20075907 \\
Ratio(\%) & 11 & 10.8 & 9.6 & 8.8 & 9.11 & 10.7 & 13 & 12.96 \\
\hline
\end{tabular}


Data sources: Guangxi Statistical Year book

Table 1 presents the situation of financial support to agriculture in Guangxi from 1995 to 2010. It shows that Guangxi local fiscal support to agriculture has been on a steady increase year by year since 1995 , with an average annual growth rate of $20.68 \%$. The rapid promotion of the increased range of fiscal expenditure commenced from 2006, and it reached twenty-six billion in 2010. However, the increase of the proportion of fiscal expenditure spending on agriculture in the total fiscal expenditure is not obvious. Contrarily, in certain years, it demonstrates the tendency of decreasing. The agricultural expenditure in 2006, accounting for $8.8 \%$ of total financial expenditure that year, is the lowest portion over the years, and then it rose to $13 \%$ in 2009, declining again in 2010 .

\subsection{Agricultural loans}

The characteristic of agricultural production has made it difficult for agriculture to get the loans from financial institutions, and most of the loans are micro loans. Nevertheless, it is these characteristics that contribute to the situation that most lenders are generally agricultural entrepreneurs or local economic elites. These financial funds, judged by market economics, should be more likely to achieve capital appreciation compared to financial support (from government) to agriculture, and thus might play a positive role for the development of Guangxi-ASEAN agricultural trade.

Table 2. Guangxi financial agricultural loan table unit: ten thousand yuan

\begin{tabular}{cccccccc}
\hline year & 1995 & 2000 & 2005 & 2006 & 2007 & 2008 & 2009 \\
\hline agricultural loan & 66.1 & 107.85 & 298.44 & 337.08 & 373.94 & 407.22 & 570.2 \\
Total loan & 1055.67 & 1613.25 & 3056.86 & 3595.25 & 4287.79 & 5066.68 & 7268.41 \\
ratio(\%) & 6.26 & 6.69 & 9.76 & 9.38 & 8.72 & 8.04 & 7.84 \\
\hline
\end{tabular}

Data sources: Guangxi Statistical Yearbook

The financial support to agriculture is shown in table 2. The agricultural loans from financial institutions are in the similar situations as agriculture support discussed above. The amount of agricultural loan is increasing year by year; however, the growth of the proportion of it in the total loan amount is not very obvious. The average annual growth rate was $15.45 \%$ from 1995 to 2009 , but the proportion of agricultural loans in total loans of financial institutions has changed little. The annual average proportion of agricultural loans in the total loans was $8.1 \%$. It was $6.26 \%$ in 1995 and the highest portion $9.76 \%$ appeared in 2005 , but it declined to $7.84 \%$ in 2009 .

\subsection{Agricultural insurance}

Agricultural insurance regime is not only an important part of agricultural insurance, but also is one of the most important international non-price agricultural protection tools. ${ }^{[1]}$ It is conducive to resist natural risk, to increase the competitiveness of agricultural products and to ensure agricultural development strength, particularly in the context of trade liberalization. Guangxi agricultural insurance started early, yet it developed slowly. The proportion of agricultural insurance in the total property insurance is very small. Table 3 shows that the average agricultural insurance income in Guangxi is around $1.1 \%$ from 1996 to 2010 . The proportion of agricultural insurance in property insurance was $0.20 \%, 0.15 \%$, and $0.25 \%$ respectively from 2004 to 2006 , the span of which just coincided with the golden age of the development of Chinese-ASEAN agricultural trade. Chinese agricultural products tariff rate beginning to decrease in 2004, fell to $0 \%$ in 2006 . Undoubtedly in such good Chinese-ASEAN trade policy environment, what Guangxi has done in the agricultural insurance investment is not enough. 
Table 3. Agricultural insurance in Guangxi

\begin{tabular}{cccccccc}
\hline year & $\mathbf{1 9 9 6}$ & $\mathbf{2 0 0 5}$ & $\mathbf{2 0 0 6}$ & $\mathbf{2 0 0 7}$ & $\mathbf{2 0 0 8}$ & $\mathbf{2 0 0 9}$ & $\mathbf{2 0 1 0}$ \\
\hline $\begin{array}{c}\text { Agriculture insure } \\
\text { (ten thousand) }\end{array}$ & 1318 & 347 & 702 & 2716 & 12863 & 13105 & 7454 \\
Total insure (ten thousand) & 107528 & 238790 & 279873 & 371327 & 429804 & 527932 & 691943 \\
Ratio (\%) & 1.225 & 0.145 & 0.250 & 0.731 & 2.992 & 2.482 & 1.077 \\
\hline
\end{tabular}

Data sources: Guangxi Statistical Yearbook

\section{Guangxi agriculture financial support, agricultural insurance, agricultural loans effect to Guangxi-ASEAN agricultural products trade}

\subsection{Index selection}

This paper adopts the gross import-export volume of agricultural products trade between Guangxi and ASEAN as explained variables. Import is represented by LnIM and export is symbolized by LnEX. All data in this paper are calculated on the basis of real exchange rate of RMB to USD of the same year in order to eliminate the impact of exchange rate changes on the model. The data of Guangxi agriculture financial support, agricultural loans and agricultural insurance from 1996 to 2010 are taken as variables, represented as LnFSFA, LnFLA, and LnAI respectively after logarithm.

\subsection{Data sources and processing}

The data on agriculture financial support, agricultural loans and agricultural insurance comes from Guangxi statistical yearbook from 1996 to 2010. The data of Guangxi-ASEAN agricultural products trade is borrowed from Nanning customs. The exchange rate from 1996 to 2010 was quoted from the official website of Foreign Exchange Management Bureau. Additionally, the data on agricultural loans in 2010 was a prediction based on previous data by implementing a regression model. In order to eliminate the effects of inflation, all the data are calculated with the year of 1996 as the base period and with methods such as GDP deflator.

\subsection{The econometric model}

Local agriculture fiscal support, agriculture loans and agricultural insurance investment are beneficial to the local agricultural production from the perspective of economics. Particularly the loans for agricultural enterprise and insurance for some industrial crops are conducive to strengthening the mobility of agricultural products trade. The increase of fiscal expenditure for agriculture will undoubtedly promote the income of farmers, and consequently will stimulate the purchase of some scarce agricultural product. Guangxi and ASEAN nations, especially Vietnam, Laos, Thailand, Kampuchea and so on are involved in so frequent agricultural products trade, on which might the shift of invested agricultural capitals be reflected in a short run. Here come the following three hypotheses with a preliminary analysis of Guangxi-ASEAN agricultural products trade and of the three agricultural funds:

Assumption 1: Local agriculture financial support, agriculture loans and agricultural insurance have certain influence (either positive or negative) on the imports of agricultural products from ASEAN.

Assumption 2: Local agriculture financial support, agriculture loans and agricultural insurance have certain influence (either positive or negative) on the export of agricultural products to ASEAN. 
Those two assumption are represented by the below model

$$
\begin{aligned}
& L n I M=\alpha+\beta L n F S F A+\delta L n F L A+\gamma L n A I+U \mathrm{t} \\
& L n E X=\alpha+\beta L n F S F A+\delta L n F L A+\gamma L n A I+U \mathrm{t}
\end{aligned}
$$

Ut stands for Random error, and the positive value of $\beta, \delta, \gamma$ represents positive relevance and the negative value of them the negative relevance.

\section{Unit root test}

With the help of eviews6.0, ADF unit root is applied to test the stability of variables namely Guangxi-ASEAN agricultural product including import and export (LnIM/LnEX), agriculture support funds (LnFSFA), agricultural loan funds (LnFLA) and agricultural insurance funds (LnAL). The specific type of test (to determine whether with the intercept or trend) is confirmed in accordance with the original variables and difference variable trend line (figure2 and 3). The optimal lag of tests is determined automatically by Eviews6.0 based on the Schwartz information criterion (SIC). Results pictured in Table 4 shows that Guangxi -ASEAN import and export (LnIM/LnEX), fiscal support for agriculture fund (LnFSFA), the agricultural loan fund (LnFLA) is with non-stability in the current sequence test and then all become stable after a differential, and the agricultural insurance fund (LnAL) in the current series is stable. The paper uses the finite difference method, $\Delta^{\mathrm{n}}$ indicated to $\mathrm{n}$ time difference of index (this paper use only the first order difference). After unit root test, all variables go througha difference and integration, under the significance level of 5\%,10\%.

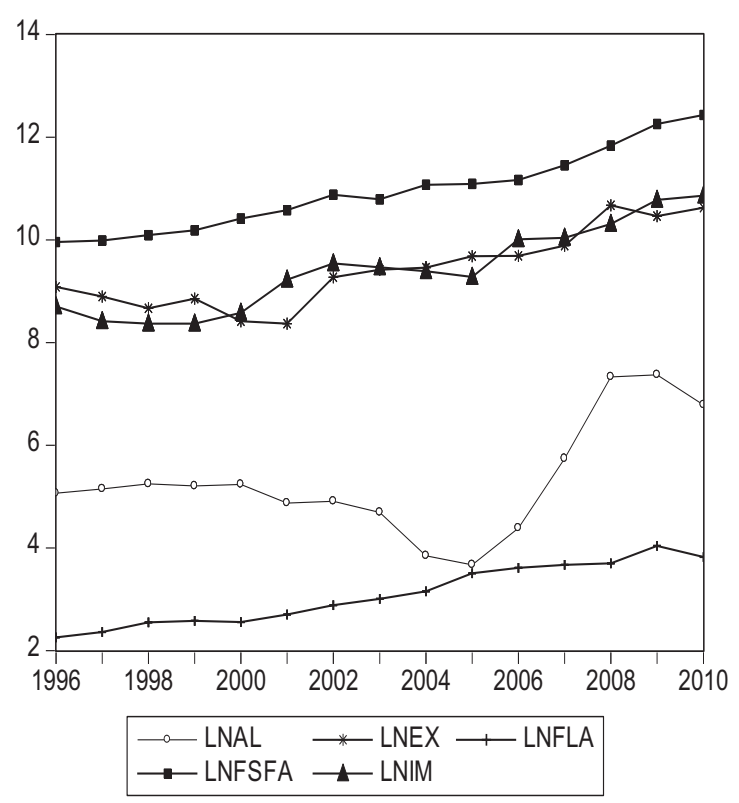

Figure2. Trendline before difference variables 


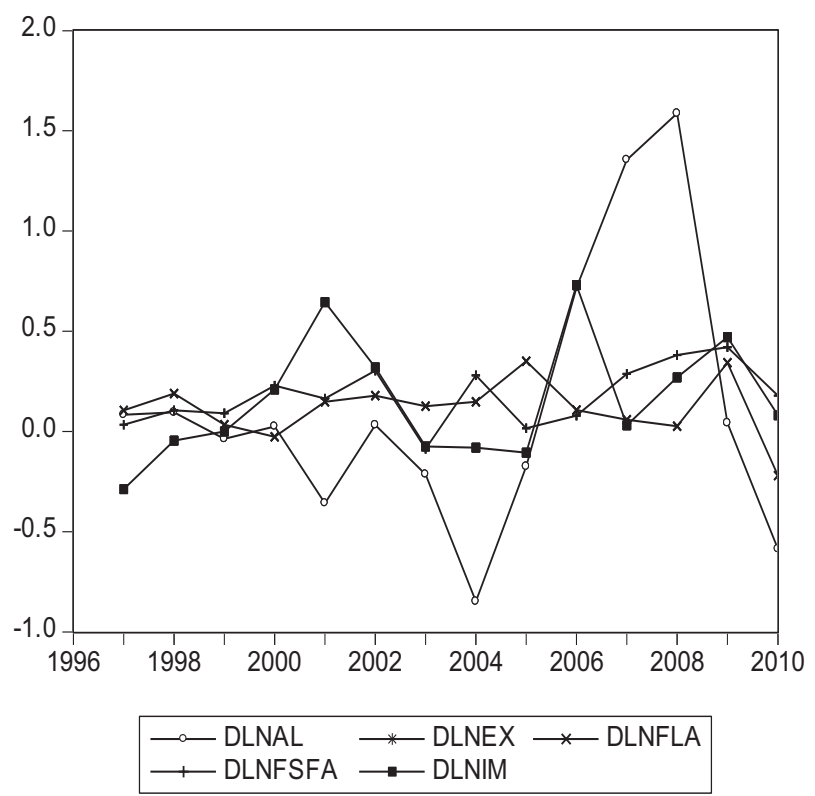

Figure3. Trendline after difference variable

Table 4. Unit test of varies

\begin{tabular}{|c|c|c|c|c|c|c|}
\hline \multirow{2}{*}{$\begin{array}{l}\text { varies } \\
\operatorname{lnim}\end{array}$} & \multirow{2}{*}{$\begin{array}{c}\text { type of } \operatorname{test}(\mathbf{C} \mathbf{T} \mathbf{K}) \\
(\mathrm{C}, \mathrm{T}, 3)\end{array}$} & \multirow{2}{*}{$\begin{array}{c}\text { ADF statistic } \\
-2.9625\end{array}$} & \multicolumn{2}{|c|}{ significance level(5\%) } & \multicolumn{2}{|c|}{ significance level(10\%) } \\
\hline & & & -3.8290 & non-stable & -3.3690 & non-stable \\
\hline $\mathrm{d}(1)$ & $(0,0,2)$ & -2.5910 & -1.9710 & stable & -1.6037 & stable \\
\hline $\operatorname{lnex}$ & $(\mathrm{C}, \mathrm{T}, 3)$ & -2.7605 & -3.8290 & non-stable & -3.3630 & non-stable \\
\hline $\mathrm{d}(1)$ & $(0,0,2)$ & -2.5910 & -1.9710 & stable & -1.6037 & stable \\
\hline $\operatorname{lnfsfa}$ & $(\mathrm{C}, \mathrm{T}, 3)$ & -1.1915 & -3.7912 & non-stable & -3.3423 & non-stable \\
\hline $\mathrm{d}(1)$ & $(\mathrm{C}, 0,2)$ & -3.3354 & -3.1200 & stable & -2.7011 & stable \\
\hline $\operatorname{lnfla}$ & $(\mathrm{C}, \mathrm{T}, 3)$ & -2.4598 & -3.7912 & non-stable & -3.3423 & non-stable \\
\hline $\mathrm{d}(1)$ & $(\mathrm{C}, 0,2)$ & -4.1783 & -3.1200 & stable & -2.7011 & stable \\
\hline lnai & $(\mathrm{T}, 0,3)$ & -3.5596 & -3.1200 & stable & -2.7011 & stable \\
\hline $\mathrm{d}(1)$ & $(0,0,2)$ & -2.8327 & -1.9740 & stable & -1.6029 & stable \\
\hline
\end{tabular}

note: $\mathrm{C}$ represents constant term ( 0 means non- constant term), $\mathrm{T}$ represents trend term $(0$ means nontrend term), K represents lag order. 


\section{Co-integration test}

Table 4 shows that all variables are integration through the unit root test, that is I(1). Therefore, it had the conditions to make the co-integration test for each index by using the Johansen test method. Table 5 shows that there are 3 co-integration relationships between LnIM and LnFSfA, LnEX, LnFLA, the optimal co-integration equation is:

$$
\begin{aligned}
& \mathrm{LnIM}=-2.5161 * \mathrm{LnFSFA}+1.6725 \mathrm{LnFLA}+0.08678 \mathrm{LnAI}+12.2544 \\
& \begin{array}{llll}
(0.0650) & (0.0773) & (0.0111) & (0.44790)
\end{array}
\end{aligned}
$$

This equation displays that, among all the related funds to support agriculture, local agricultural support funds has negative correlation on Guangxi agricultural products trade import, agricultural loans and agricultural insurance has positive correlation on Guangxi agricultural products trade import. Therefore, hypothesis 1 passes the test, namely the local agriculture financial support, agricultural loans and agricultural insurance have a certain influence on Guangxi-ASEAN agricultural products trade imports. At the same time, Table 6 demonstrates that there are three co-integration relationships between LnEX and LnFSFA, LnE, LnFLA, whose optimal co-integration equation is:

LnEX=1.1063LnFSFA-1.0900LnAI-3.2197LnFLA

$$
\text { (0.2060) (0.0353) (0.2450) }
$$

Indicating the local agricultural fiscal expenditure has positive correlation for the export of Guangxi to ASEAN. On the contrary, agricultural insurance and agricultural loans have negative correlation to the export for Guangxi, agricultural insurance and agricultural loans showed inhibitory effect on Guangxi exports. As a result, hypothesis 2 passes the test, namely local agriculture financial support, agriculture loans and agricultural insurance have a certain impact for Guangxi export agricultural products to ASEAN. However, the value of $\mathrm{P}$ inside the brackets in the model is not significant and the model fitting degree is not high, so the conclusion is not very clear whether related agriculture funds have impact on Guangxi-ASEAN agricultural products trade. But it is noteworthy that the agriculture financial support, agricultural loans and agricultural insurance show the opposite trend for import and export. Therefore, the above conclusion is relatively convincing.

Table 5. The co-integration test results (IM)

\begin{tabular}{ccccc}
\hline $\begin{array}{c}\text { null hypothesis:set the } \\
\text { number of cointegration } \\
\text { vector }\end{array}$ & $\begin{array}{c}\text { characteristic } \\
\text { value }\end{array}$ & trace statistic & significance level 5\% & P value \\
\hline At most one * & 0.9327 & 62.7287 & 35.1928 & 0.0000 \\
At most two * & 0.7577 & 27.6497 & 20.2618 & 0.0040 \\
At most three * & 0.5081 & 9.2231 & 9.1645 & 0.0487 \\
\hline
\end{tabular}

* Accept the null hypothesis at the 5\% significance level

Table 6. The co-integration test results (EX)

\begin{tabular}{ccccc}
\hline $\begin{array}{c}\text { null hypothesis:set the } \\
\text { number of co-integration } \\
\text { vector }\end{array}$ & $\begin{array}{c}\text { characteristic } \\
\text { value }\end{array}$ & trace statistic & significance level 5\% & P value \\
\hline $0^{*}$ & 0.9944 & 103.8251 & 47.8561 & 0.0000 \\
at most one * & 0.7884 & 36.3206 & 29.7971 & 0.0077 \\
at most two * & 0.5772 & 16.1300 & 15.4947 & 0.0401 \\
at most three * & 0.3160 & 4.9376 & 9.8415 & 0.0263 \\
\hline
\end{tabular}


* Accept the null hypothesis at the 5\% significance level

Due to limitation of data, in this paper, it is not possible to test the error correction model. In order to test the results of Johansen co-integration test reliability. Engle-Granger two-step test method as supplement was used to test co-integration relations. From the co-integration theory, if there is a co-integration relationship between the explanatory variables and the dependent variable, namely interpreted variable can be explained by a linear combination of the explanatory variables, and the part that cannot be explained by the explanatory variables constitute a part of residuals, and then the residuals should be stationary. Thus, to test the existence of co-integration is equivalent to testing whether the estimated residuals of the regression equation is a stationary series. Firstly, this paper use OLS method estimated import and export of Guangxi-ASEAN with agriculture financial support, agricultural insurance, agricultural loans respectively to get regression equation. And then we calculated the corresponding residuals reside and residim based on these regression equations. At last, we used ADF unit root test for each of these residuals. As shown from Table 8, residex and residim are stationary sequence at the $1 \%$ significance level. To further validate that the Guangxi-ASEAN trade of agricultural products and "three agriculture-related funds" does exist in long-term stability, namely co-integration.

Table 7. Import residuals resid of ADF unit root test results

\begin{tabular}{ccccccc}
\hline varies & type of test(C T K) & ADF statistic & \multicolumn{2}{c}{ significance level(5\%) } & \multicolumn{2}{c}{ significance level(10\%) } \\
\hline residex & $(0,0,3)$ & -3.469 & -2.7406 & stable & -1.9684 & stable \\
residim & $(0,0,3)$ & -3.4248 & -2.7406 & stable & -1.9684 & stable \\
\hline
\end{tabular}

note: $\mathrm{C}$ represent constant term (0 means non- constant term), $\mathrm{T}$ represent trend term (0 means nontrend term), K represent lag order.

\section{Conclusions and Suggestions}

By the empirical analysis of Guangxi-ASEAN agricultural trade from1995to2010, we conclude that agriculture financial support, agricultural insurance, agricultural loans have certain correlation with Guangxi-ASEAN agricultural product trade, that is, agriculture financial support suppresses Guangxi imports agricultural products from ASEAN, and promote Guangxi exports to ASEAN. Agricultural insurance and agricultural loans promote Guangxi agricultural imports from ASEAN and are not conducive to Guangxi export agricultural products to ASEAN. The results also verify the correctness of the hypothesis that agriculture financial support, agricultural loans and agricultural insurance have the opposite influence upon exports and imports in Guangxi-ASEAN agricultural trade. This is also consistent with the facts.

Agriculture is a vulnerable industry, so it is difficult to attract capital into the agricultural sector in the interest-driven market economy. Guangxi is located in the Southwest and primary industry is still an important part of the revenue of Guangxi. Therefore, making better use of agricultural funds is particularly important. Vietnam, Thailand, Cambodia, Laos and other agriculture-based ASEAN countries have closely agricultural trade with Guangxi. Based on findings of the paper, we propose what follows.

(1) Increase financial support for agriculture, and improve the quality of agricultural products. The results can be derived from the model that fiscal funds to support agriculture having a positive correlation for Guangxi to export agricultural trade to ASEAN. There is intense competition between Guangxi and ASEAN countries because of similarity in climate and agriculture produce. Therefore, to increase financial support for agriculture and improve the quality of agricultural products will increase Guangxi-ASEAN agricultural trade surplus and promote the development of Guangxi 
agriculture.

(2) The results of model show that Guangxi agricultural loans has a very low positive effect (coefficient is +0.08678 ) on imports of agricultural products, but has a larger negative effect (coefficient of -1.0900) exports of agricultural products. Guangxi agricultural loan does not promote exports of agricultural products to ASEAN. This paper gives two tentative explanations for the result. One is the small sample data collected in this article, leading to the results of the export model fitting degree and low significant level. Second is structural imbalance in Guangxi agricultural loans. Most loans in Guangxi was mainly targeted at infrastructure, health care, business, etc. Loans for agriculture mainly goes to sugar cane, cocoon, cassava and other traditional agriculture industries, ignoring other agriculture produce. Facing diversified ASEAN agricultural products, Guangxi often present inadequate competitiveness with ADSEAN countries.

(3) Considering the actual situation of Guangxi, we suggest a agricultural insurance with appropriate insurance coverage suitable to Guangxi. The results of the model demonstrate that Guangxi agricultural insurance fund is scarcely relative to the agriculture financial support and agricultural loans. But agricultural insurance have a great impact on Guangxi agricultural products exporting to or importing to from ASEAN (export coefficient is -3.2197, import coefficient of +1.6725 ). So taking features of Guangxi agricultural insurance into account, this paper suggests that the relevant government agencies and insurance companies support and improve agricultural insurance, and develop specialized agricultural insurance system against natural disasters or fitting characteristics long agricultural cycle. For example, agricultural insurance policy for sugar cane, cassava and so forth.

\section{References}

1. Xu Jialei, Ji Weiwei, Xiong Deping. Chinese agricultural investment in agricultural foreign trade[J].World Agriculture,2010(11),31-32

2. Zhang Jianzhong. Guangxi-ASEAN agriculture weakness and trade competitiveness of agricultural research[J]. International Business,2009(12),63-67.

3. Peng Keqiang, Chinese grain production revenue and its influencing factors co-integration analysis[J],Chinese Rural Economy, 2009(6).

4. Li Yan, Economic Analysis of Guangxi Agricultural Insurance Development Dilemma[J], Anhui Agricultural Science and Technology, 2011. 